\title{
DUKUNGAN TERHADAP ODHA UNTUK MENGHILANGKAN PERASAAN INFERIORITAS
}

\author{
Vigih Riani \\ Fakultas Psikologi \\ Universitas Ahmad Dahlan \\ vigihapril2017@gmail.com
}

\begin{abstract}
Abstrak
Tujuan penulisan ini adalah untuk mengetahui gambaran mengenai inferioritas dan berpikir positif pada Orang dengan HIV/AIDS (ODHA). Subjek penulisan ini adalah Orang dengan HIV/AIDS (ODHA) di Yayasan Victory Plus. Metode pengumpulan data dengan observasi dan wawancara. Hasill menunjukkan bahwa ODHA merasa bahwa dirinya tidak memiliki kemampuan dan selalu merasa bahwa apa yang dilakukan selalu salah dan buruk dimata masyarakat. Hal tersebut yang memunculkan adanya inferioritas. Perasaan inferioritas menjadi salah satu faktor masalah orang dengan HIV/AIDS. ODHA yang memiliki perasaan inferioritas akan selalu berpikir negatif terhadap dirinya sendiri dan akan selalu fokus terhadap kekurangan yang dimilikinya. Yayasan Victory Plus Yogyakarta menjadi wadah untuk memberikan dukungan terhadap ODHA agar dapat mengatasi permasalahan inferioritas yang dialami dan menanamkan pikiran positif dalam diri ODHA
\end{abstract}

Kata Kunci: berpikir positif. Inferioritas, ODHA

\section{PENDAHULUAN}

Setiap manusia mengalami proses perubahan yang berlangsung sepanjang hidupnya. Perubahan yang terjadi pada setiap individu disebabkan dari berbagai faktor. Menurut Wahyu (2012) salah satu faktor yang harus menjadi perhatian dan mempunyai peran besar dalam perkembangan individu adalah faktor kesehatan. Faktor kesehatan mempengaruhi perkembangan yang dimiliki setiap individu, karena jika individu memliki tubuh yang sehat maka perkembangan dan pertumbuhan setiap individu akan berjalan dengan baik. Ketika individu terkena penyakit maka akan menghambat setiap proses pertumbuhan . salah satu contoh penyakit yang banyak ditakuti oleh banyak orang yaitu HIV (Human Immunodeficiency Virus) /AIDS (Acquired Immune Deficiency Syndrome). Penyakit tersebut merupakan salah satu 
penyakit yang menghambat pertumbuhan setiap individu sehingga tidak dapat melakukan aktivitas seperti sebelumnya.

Individu yang terkena penyakit HIV (Human Immunodeficiency Virus) /AIDS (Acquired Immune Deficiency Syndrome) maka akan merasa bahwa kehidupanya sudah berakhir. Kebanyakan orang yang mengidap penyakit tersebut rentan mengalami perubahan yang drastis dalam hidupnya. Aktivitas yang mereka lakukan seperti biasa sebelum terkena penyakit tersebut pun akan berubah. seperi yang dijelaskan oleh Wahyu (2012) banyak perubahan yang terjadi dalam diri individu setelah terinfeksi HIV/AIDS, penyakit yang mereka derita ini mempengaruhi kehidupan pribadi, sosial, belajar, karir dan kehidupan keluarga.”

Perubahan tersebut membuat ODHA akan mempunyai persepsi negatif terhadap dirinya. Hal tersebut pernah dipaparkan oleh salah satu pendiri yayasan pemberdaya ODHA yang ada di Yogyakarta yaitu yayasan victory plus yogyakarta sewaktu kami melakukan observasi dan wawancara terhadap yaysan mengenai ODHA yang ada di yogyakarta, dia memaparkan bahwa ODHA akan selalu merasa mereka tidak dibutuhkan dimasyarakat sehingga membuat mereka mengurung diri dari lingkungan sosialnya. Perasaan rendah diri menjadi salah satu faktor masalah yang ada pada ODHA, ketika mereka memiliki perasaan rendah diri atau inferioritas maka mereka akan selalu berpikir negatif terhadap diri mereka sendiri mereka akan lebih fokus terhadap kekurangan yang ada pada diri mereka sendiri.

berdasarkan pemaparan diatas maka penulis tertarik untuk membahas dukungan Yayasan Victory Plus Yogyakarta terhadap ODHA untuk menghilangkan perasaan inferioritas dan menanamkan berpikir positif pada ODHA.

\section{PEMBAHASAN}

Menurut Hall dan Lindzey (1993) inferioritas adalah perasaan-perasaan yang muncul akibat ketidaksempurnaan psikis berupa perasaan tidak mampu, tidak dicintai yang dirasakan secara subyektif maupun perasaan-perasaan yang muncul dan kelemahan/cacat tubuh yang nyata. Individu yang memiliki perasaan inferioritas akan 
selalu berpikir negative terhadap segala sesuatu yang mereka lihat dari diri mereka sendiri. Menurut adler dalam suryabrata (2005) inferioritas adalah perasaan yang muncul akibat hambatan psikis dan sosial yang dirasakan secara subyektif maupun perasaan-perasaan yang muncul dan kelemahan.

Faktor-faktor yang menyebabkan munculnya perasaan inferioritas atau rendah diri yaitu salah satunya karena merasakan kecacatan fisik maupun psikis. Sehingga mereka susah untuk menerima kekurangan yang ada pada diri sendiri. kurangnya penerimaan diri tersebut akan menyebabkan hambatan pergaulan dalam masyarakat individu tidak dapat bersosialisasi dengan masyarakat yang lebih luas (Tentama, 2012). Rasa rendah diri tersebut perlu dihilangkan karena dapat menghambat potensi yang dimiliki menjadi tidak tereksplorasi.

Dampak dari inferioritas ketika individu memiliki perasaan inferior karena kekurangan dalam dirinya maka dapat mempengaruhi penerimaan dirinya atau selfacceptencenya. (Tentama, 2011) Individu yang memiliki perasaan rendah diri yang tinggi akan kesulitan menerima kekurangan yang ada didalam dirinya . Sehingga mereka membutuhkan. dukungan dari berbagai pihak, agar mereka mampu untuk menerima dirinya kembali untuk menjadi lebih baik dengan kemampuan yang mereka punya. Penerimaan diri (self-acceptance) merupakan suatu tingkat kesadaran individu tentang karakteristik kepribadianya, akan kemauan untuk hidup dengan keadaan tersebut (Hurlock, 1994). salah satu yayasan yang mendukung pemberdayaan ODHA yang ada di Yogyakarta yaitu yayasan victory plus.

Dari data yang kami dapat dari hasil penelitian observasi dan wawancara terhadap Yayasan Victory Plus yang ada di Yogyakarta, pendiri dan staf yang ada di yayasan tersebut memiliki cara tersendiri untuk mendukung ODHA yang mengalami perasaan inferior agar dapat menghilangkan perasaan tersebut dari penderita. Karena jika ODHA mengalami perasaan inferiror maka ODHA akan rentan depresi sehingga berdampak negatif didalam hidupnya. Berbagai upaya perlu dilakukan untuk membantu ODHA agar menghilangkan perasaan inferior sangat penting sehingga kembalinya perasaan percaya diri melalui proses belajar. Upaya peningkatan 
kepercayaan diri bagi remaja yang mengalami hambatan kepercayaan diri dapat dilakukan dengan proses belajar dan bertatih (Lauster, 1978; Hambly, 1992).

\section{SIMPULAN}

Berdasarkan hasil wawancara dan observasi disimpulkan bahwa ODHA yang mempunyai perasaan inferior maka akan berdampak buruk terhadap kehidupannya dimasa yang akan datang, karena mereka akan cenderung berpikir negatif terhadap diri mereka sendiri mereka merasa bahwa mereka tidak memiliki kemampuan dan selalu merasa bahwa apa yang mereka lakukan selalu salah dan buruk dimata masyarakat. Dengan adanya Yayasan Victory Plus untuk pemberdayaan ODHA khususnya di Yogyakarta maka akan mendukung ODHA yang rentan mengalami perasaan rendah diri yang berakibat tidak memiliki kesempatan seperti orang pada umumnya dengan metode yang digunakan di yayasan tersebut.

\section{DAFTAR PUSTAKA}

Hall, C. S., \& Lindzey, G. (1993). Psikologi kepribadian 1 teori-teori psikodinamik (klinis). Yogyakarta: Kanisius.

Hambly, K. (1992). Bagaimana Meningkatkan Rasa Percaya Din'. (Alih Bahasa: Budiyanta). Jakarta: Arcan.

Hurlock, E. B., Istiwidayanti, Sijabat, R. M., \& Soedjarwo. (1990). Psikologi perkembangan: Suatu pendekatan sepanjang rentang kehidupan. Erlangga, Jakarta.

Lauster, P.(1978). The personality test (2nd. Ed.). London: Pan Books, Ltd.

Suryabrata,S.,(2005). Psikologi kepribadian. Jakarta: PT Raja Grafindo Persada.

Tentama, F. (2011) . Hubungan inferioritas dengan self-acceptance pada penyandang tuna daksa. Prosiding seminar nasional, 15-25. Yogyakarta: Kopertis wilayah V.

Tentama, F. (2012). Mengatasi inferioritas difabel. Harian jogja.

Wahyu, S., Taufik, T., \& Ilyas, A. (2012). Konsep Diri dan Masalah yang Dialami Orang Terinfeksi HIV/Aids. Konselor, 1(2). 